\title{
Trade Credit In Zimbabwe's Economic Recovery
}

\author{
Farai Kwenda \\ Lecturer, School of Accounting, Economics and Finance, \\ University of KwaZulu-Natal, South Africa \\ email: kwendaf@ukzn.ac.za
}

\section{Doi:10.5901/mjss.2014.v5n2p431}

\begin{abstract}
The aim of this study is to investigate factors influencing the use of trade credit by Zimbabwean manufacturing firms. Zimbabwe's economy is on a recovery path after the decade-long political, social and economic crises. The recovery of the Zimbabwean economy has been largely hampered by a number of factors; chief among them, poor liquidity and difficulties in accessing working capital finance. The study is based on secondary data of 48 firms listed on the Zimbabwe Stock Exchange. The study found that firm size, investments in current assets and access to external funds influence the use of trade credit among these firms.
\end{abstract}

Keywords: Accounts payable, accounts receivable, economic recovery, dollarisation, liquidity.

\section{Introduction}

Under perfect capital market conditions, the choice of financing instrument is supposed to be a non-issue in corporate financing because internal and external finance are perfect substitutes. This means trade credit is supposed to be irrelevant under such conditions. However, empirical evidence suggests that for most non-financial firms by trade credit represents a significant source of financing (Deloof \& Jegers, 1999; García-Teruel \& Martínez-Solano, 2010; Petersen \& Rajan, 1997). Trade credit makes up about $41 \%$ and $35 \%$ of total debt among medium sized UK and USA firms respectively and represents more than $50 \%$ of short term debt in both countries (Cunat, 2007).

The importance of trade credit as a source of financing differs among countries and its importance is likely to be more pronounced in manufacturing-oriented countries (Khan, Tragar, \& Bhutto, 2012). Private trade credit markets had an influential role in the economic transition of Poland according to Coricelli and Masten (2004). In trying to explain the Chinese economic growth puzzle, Cull, Xu, and Zhu (2009) found that supplier credit did not play an influential role in the growth of the Chinese firms. In developing countries, limited access to formal finance amplifies the significance of trade credit in financing the firm's short-run operations (Fisman, 2001). In countries with poorly developed financial sector, firms in industries which greatly depend on supplier finance had high growth rates (Fisman \& Love, 2003).

\section{Background to the Study}

Zimbabwe underwent a decade long political, social and economic crises which almost brought the whole country to its knees. Political polarization, declared and undeclared economic sanctions, poor rains and harvests, corruption were of the key factors that were blamed for the crises (Reserve Bank of Zimbabwe, 2005). As a result, the crises were characterized by a runaway hyperinflation, acute scarcity of basic commodities, a thriving black market of basic commodities and foreign currency, massive increases in unemployment, a massive exodus of both skilled and unskilled labour out of the country among others. Zimbabwe reported a whopping 47.26 percent cumulative decline between 1999 and 2007 (International Monetary Fund, 2008) in its Real Gross Domestic Product (RGDP) and set a world record of an increase in the annual rate of inflation ${ }^{1}$.

The formation of the government of national unity (GNU) by the country's major political parties and the adoption

1. The inflation rate rose from 15.8 percent in January 1997 (Ministry of Finance, 2006) to 231150888.87 percent in July 2008 (Central Statistical Office, 2008) 
of the multiple-currency system (hereinafter dollarisation²) in 2009 ushered the country into a new political, social and economic dispensation. The GNU managed to stabilize the inflation rate, with the month-on-month inflation rate falling and fluctuating between $-3.1 \%$ and $1.1 \%$ between 2009 and 2012. As shown in Table 1, the country managed to register positive economic growth and improve capacity utilization in the manufacturing sector. Other key sectors of the economy (agriculture, mining and retail) were also set on a revival path. The country also managed to improve public service delivery, restore the overall business confidence and working relations with the international community (Ministry of Finance, 2010, pp. 11-12).

Table 1: RGDP growth and Capacity Utilisation of Zimbabwe's Manufacturing Firms

\begin{tabular}{|l|c|c|c|c|c|}
\hline \multicolumn{1}{|c|}{ Year } & 2008 & 2009 & 2010 & 2011 & 2012 \\
\hline RGDP growth & - & $5.4 \%$ & $8.1 \%$ & $9.4 \%$ & $4.4 \%$ \\
\hline Capacity Utilisation & $10 \%$ & $30 \%$ & $43 \%$ & $57 \%$ & $60 \%$ \\
\hline Growth rate & $-17 \%$ & $10.2 \%$ & $2.7 \%$ & $5.7 \%$ & $6 \%$ \\
\hline
\end{tabular}

Source: Confederation of Zimbabwe Industries (2011); (Ministry of Finance, 2010, 2011, 2012)

Despite these notable achievements the economy scored, there are several structural challenges inhibiting economic growth. These include among others; lack of capital, foreign direct investment, the liquidity crunch and the high cost of money, lack of fiscal space, debt overhang, lack of project implementation capacity, skills gap, energy, high cost of utilities, high labour costs and hyperinflation hangover (Ministry of Finance, 2010, p. 3). Three main challenges facing the manufacturing sector are low demand, machine breakdown and limited access and / or the prohibitive cost of working capital in the local market (Confederation of Zimbabwe Industries 2011; Ministry of Finance, 2012).

The main objective of this study is to examine the determinants of trade credit (accounts payable) among Zimbabwean non-financial firms. Bank credit availability is limited which this means that supplier financing assumes inflamed importance as a source of finance. Trade credit can compensate for unavailability of credit from financial institutions (Fisman \& Love, 2003). The decade long crises regressed Zimbabwe's financial development it had achieved in the post-independence era, in particular the liberisation of the financial sector in the early 1990s. There is a serious lack of confidence and stability in country's Zimbabwean financial sector, for example in November 2012, the Reserve Bank of Zimbabwe failed to successfully sell its Treasury Bills. The current financial system in Zimbabwe can be classified as shallow and not well-developed. Most transactions at individual, household and corporate level are done on credit basis due to the liquidity challenges. Hence the need to analyse the role of trade credit in corporate financing in Zimbabwe's economic recovery.

The rest of the paper is organised as follows: Section 2 briefly reviews the literature on trade credit. Data sources and the sample are described in Section 3. Section 4 presents and analyses the principal findings of the study. The conclusion of the study is presented Section 5 .

\section{Literature Review}

\subsection{Introduction}

Trade credit is when sellers supply goods and allow buyers a short period of time before the payment is due. The unsynchronized timing of disbursements and payment for goods and services means that trade credit can be regarded as a short-term loan tied in both timing and value to the exchange of goods provided by a supplier to its customers (Ferris, 1981; Van Horne, 2002). Trade credit is important to most firms because of its dual nature; most companies simultaneously buy their goods on credit (which creates accounts payable) and sell their goods on credit (which creates accounts receivable). Consequently, trade credit represents a major source of short-term funds that is used primarily to finance receivables and acquisition of inventory.

\footnotetext{
2. Zimbabwe adopted the multicurrency in Febraury 2009. The main currencies used the south Africa Rand (ZAR), the Botswana Pula (BP), the United States Dollar (USD\$) and the British Pound (GBP).
} 


\subsection{Trade credit theories}

Trade credit is as old as commerce itself. A number of theories have been put forward to explain the extension of trade credit by suppliers and its use by buyers as a source of finance despite its high cost after factoring in implicit costs. These theories include the financing theory, the price discrimination theory, the transaction cost theory, the information asymmetry theory, and the macroeconomic conditions theory (Emery, 1984; Ferris, 1981; Schwartz, 1974; Smith, 1987).

Modern financial management theory is beginning to question the validity of some of these theories. For example the quality guarantee theory states that receiving goods before payment allows the customer to verify whether quality and quantity of goods delivered (Long, Malitz, \& Ravid, 1993; Smith, 1987). Trade credit is implicitly guarantees that if the goods delivered do not meet the agreed standards the customer can return the goods or refuse to pay. The validity of this argument holds in first round of purchases where there is information asymmetry about the quality of the goods between the buyer and the seller. However, this theory falls short in explaining the use of trade credit in long standing business relationship where both the buyer and the seller have full information about the quality of the product.

The transaction costs theory states that it is cheaper for both the buyer and the seller to make one payment in cases where a number of deliveries are made within a month. For the seller particularly, public utilities like water and electricity authorities, it is cheaper to send out one invoice than to collect payment as soon as consumption is done. This argument used to uphold until the 1980s. Technological advancement such as the advent of electronic transfer payment system which enable customer to pay as soon consumption is made means the use of trade credit should have declined. There is no evidence that trade credit has declined since the advent of electronic transfer payment system. In fact empirical evidence shows that the use of trade credit is on the rise. For example, Van der Wijst and Hol (2002) state at the end of 1998, the accounts payable balances of US firms was $\$ 2.5$ trillion, which was approximately $25 \%$ of the total debt of these firms. This figure was almost equal to $25 \%$ of the market capitalisation of the NYSE in December 1998.

\subsection{Trade credit advantages}

Trade credit is more flexible than loans from the traditional financiers. Fafchamps (1997) states that trade creditors rely on trust and reputation, unlike banks which demand formal collateral when granting credit. There are no collateral requirements as is the case with other forms of financing. In the event of the firm experiencing financial challenges or defaulting, it is easier to stretch payments to suppliers than to renegotiate loan terms with banks. Suppliers view occasional default on trade credit with a far less critical eye than does a banker and other lenders (Van Horne, 2002). In the event of default, Huyghebaert, Van de Gucht, and Van Hulle (2007) argues that trade creditors tend to follow a more lenient liquidation policy than financial institutions. Bradelly and Rubach (2002) seems to differ with views Huyghebaert et al. (2007) by stating that trade credit is like a double edged-sword especially for small business. Their study of 131 firms filing for insolvency, trade credit was that chief cause. $66 \%$ of the respondents cited non-payment of trade credit was the major reason for their failure.

One major incentive for a firm to depend on trade credit is that it does not have an explicit cost of finance as long as payment is made within the stipulated period (Soenen, 1993; Weston, Besley, \& Brigham, 1996). Trade creditors do not normally require payment in the form of interest on the credit provided as they receive their financial reward through their profit margin on goods and services supplied. However, when implicit costs, such as higher pricing by suppliers and foregoing cash discounts, are taken into account, this seemingly "free" source of financing may prove to be rather costly.

The separation of delivery of goods and payment allows buyers to match payments for goods with income from sales. Without trade credit firms would have to pay for goods on delivery and firms would have to wait and accumulate enough cash to buy the goods. Niskanen and Niskanen (2006) argue that trade credit allows buyers to hold lower cash balances and save money accordingly since it allows a number of deliveries to be made before payment is due. For the seller trade credit represents a short term investment that generate a higher return that those obtainable in the money market.

\subsection{Factors explaining the use of trade credit and hypothesis development}

There are several internal and external factors influence the use of trade credit as a financing instrument and the extension of trade credit as a working capital investment. Among others, these include creditworthiness, the availability of internal resources, access to capital markets, asset maturity and macroeconomic conditions. Below is a discussion of these factors and their expected relationships with trade credit. 


\subsubsection{Investment in current assets}

The matching principle states that firms try to match the maturity of assets with the maturity of liabilities. By matching asset and liability the maturities firms reduce the agency problems between shareholders and bondholders (S.C. Myers, 1977). As a result, short-term assets are usually financed with short-term debt just as accounts payable, while long-term assets are financed with long-term debt or equity. The more current assets a firm holds, the more the short term financing required to finance such assets. We introduce the variable CATA, defined as the ratio of current assets to total assets and hypothesize it is positively related to accounts payable.

\subsubsection{Growth opportunities}

Firms with more growth opportunities will generally have inadequate internal resources to finance those growth opportunities and would depend a lot more trade credit; hence a positive relationship between sales growth and accounts payable. Sales growth was calculated as:

$$
s g r=\frac{\text { Sales }_{t}-\text { Sales }_{t-1}}{\text { Sales }_{t-1}}
$$

\subsubsection{Financing costs}

As the cost of borrowing increase it is expected that firms would rely more trade credit, therefore it is hypothesised to be positively related to trade credit. Financing cost was calculated as:

$$
\text { Financing costs }=\frac{\text { Financing Expenses }}{\text { Total debt-Accounts payable }}
$$

\subsubsection{Internal resources}

The Pecking Order Theory (POT) states that firms follow a certain hierarchical order in their choice of the type of financing. Firms prefer internally-generated resources to external funds and only use external sources when internal resources are insufficient. Of the external finance, firms prefer less risky debt to equity. The POT implies that profitable firms use less external finance, both debt and equity. Following the Pecking Order Theory (POT) it is hypothesized that operating cashflows (as a proxy for internal resources) is inversely related to the dependent variable because firms with more internally generated resources may have less reliance on trade credit. Operating cash flows was calculated as Profit before interest and tax plus depreciation.

\subsubsection{External sources of finance}

Short term debt and long term debt, the two main sources of external debt, can be regarded as substitutes to trade credit (Deloof \& Jegers, 1999). It is therefore hypothesised that these are inversely related to the trade credit.

\subsubsection{Supply of Trade Credit 3}

The supply of trade credit influences the amount of trade credit that the firm uses. Large firms normally do not pay their purchases in cash, the annual purchases was used a as a proxy for the supply of trade credit, following previous studies (García-Teruel \& Martínez-Solano, 2010; Khan et al., 2012; Niskanen \& Niskanen, 2000).

\subsubsection{Creditworthiness and Access to Capital Markets}

Firm size and age are used to compute the firm's creditworthiness and access to capital markets. Large firms are more creditworthy and therefore can access more trade credit than small firms. However, large firms can attract funds from wider sources; therefore they can depend less on trade credit. The natural log of total assets was used as proxy for size.

\footnotetext{
3. Firms in the sample did not disclose their Cost of Sales; therefore this variable was not included in the regression analysis.
} 


\subsubsection{Macroeconomic factors}

The state of the economy may affect trade credit levels (Smith, 1987). Worsening macroeconomic conditions may cause a spike in the accounts payable level as the firms may struggle to generate enough cash resources, resulting in delays in paying suppliers. Improving macroeconomic conditions may provoke an increase in levels of accounts payable as firms increase their inventory levels (increasing their purchases). Therefore the direction of influence of macroeconomic conditions on trade credit is not clear.

\section{Data Sources and Methodology}

\subsection{Data sources}

The study was based on secondary data of 48 non-financial firms listed on the ZSE. Firms in the financial sector were excluded because the nature of their debtors and creditors was considered different from the meaning using in this study. Data was collected from company annual reports and financial statements for the accounting period 2009 to 2012, the ZSE and ZimStats. The study uses a sample of ZSE-listed non-financial firms which are the large firms in the Zimbabwean economy and are supposedly to have better access to funding. Such firms can exercise their market power by stretch payments to small suppliers with very minimal repercussions (Hill, Kelly, \& Highfield, 2010).

\subsection{Variables and model of the study}

The relationship between accounts payables and its explanatory variables will be estimated using the empirical models given below;

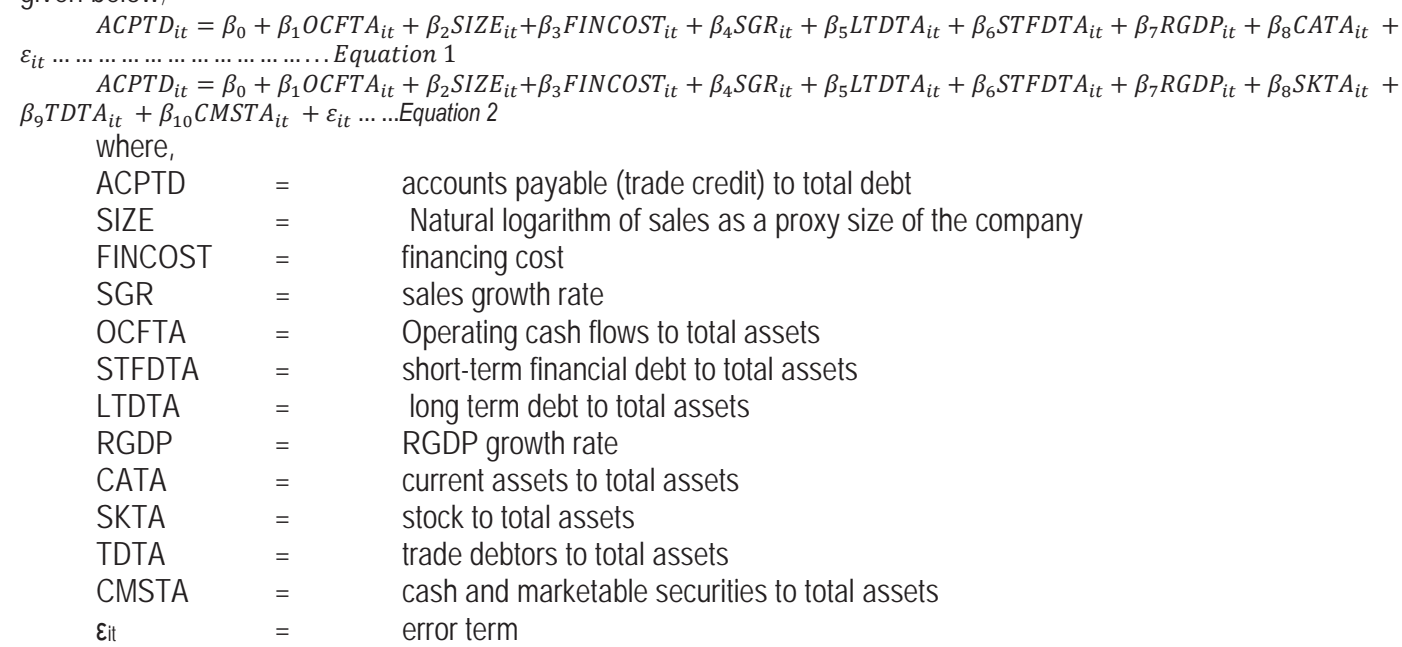

The study explores the determinants of trade credit for non-financial ZSE-listed firms using trade credit as the dependent variable and eight explanatory variables that comprise seven firm specific variables and one macroeconomic variable in Equation 1. In Equation 2 the explanatory variable CATA is disaggregated into stock to total assets (SKTA), trade debtors to total assets (TDTA) and cash and marketable securities to total assets, (CMSTA).

\subsection{Descriptive statistics}

Table 2 shows that on average accounts payable to total debt is $64 \%$ (median value is $65 \%$ ), underlining the importance of trade credit as a source of short-term external finance. On average, short term financial debt and long term debt are respectively $10 \%$ and $6 \%$ of total assets, which is very low and probably reflective of the unavailability of finance from financial institutions. The average sales growth rate is $53 \%$ while the operating cash flows have a mean value of $4 \%$. Current assets investments are $37 \%$ of total assets and of these current assets, inventories are the major investment. Inventories are $17 \%$ of total assets with a median value of $14 \%$ while trade debtors are $12 \%$ of total assets, (median 
value is $8 \%$ ). Cash and marketable securities to total assets are on average $3 \%$ (median value of $2 \%$ ) showing that firms in this sample are keeping very low levels of their as short term investments, something that could be explained by low interest in the money market or limited cash resources by these firms.

Table 2: Descriptive statistics

\begin{tabular}{|}
\begin{tabular}{|c|c|c|c|c|c|}
\hline Variable & Mean & Standard Deviation & Minimum & Median & Maximum \\
\hline Sales (US $\$ 000)$ & 67900 & 115000 & 35 & 22100 & 627000 \\
\hline SGR & 0.5331 & 1.301671 & -1.000 & 0.2700 & 8.3000 \\
\hline Sources and cost of funds \\
\hline ACPTD & 0.6377 & 0.2816 & 0.0000 & 0.6498 & 1.0000 \\
\hline STFDTA & 0.0962 & 0.1286 & 0.0000 & 0.0066 & 0.6016 \\
\hline LTDTA & 0.0499 & 0.2375 & 0.0000 & 0.0000 & 2.0272 \\
\hline FINCOST & 0.0477 & 0.3727 & 0.0000 & 0.0089 & 5.1663 \\
\hline OCFTA & 0.0384 & 0.1885 & -0.9748 & 0.0527 & 0.9980 \\
\hline Assets & 0.2260 & 0.0072 & 0.3695 & 0.8994 \\
\hline CATA & 0.3648 & 0.1513 & 0.0000 & 0.1489 & 0.9641 \\
\hline SKTA & 0.1708 & 0.1214 & 0.0000 & 0.0835 & 0.6056 \\
\hline TDTA & 0.1195 & 0.0607 & 0.0000 & 0.0160 & 0.7037 \\
\hline CMSTA & 0.0332 &
\end{tabular}
\end{tabular}

Source: Own calculations based on financial reports obtained from company annual reports.

\subsection{Correlation analysis}

The relationships in the correlation matrix follow presented in table 3 have mixture of expected and unexpected results.

Table 3: Correlation Matrix

\begin{tabular}{|c|c|c|c|c|c|c|c|c|c|c|c|c|}
\hline & ACPTD & SIZE & CATA & SKTA & TDTA & CMSTA & SGR & OCFTA & STFDTA & LTDTA & FINCOST & RGDP \\
\hline ACPTD & 1.000 & & & & & & & & & & & \\
\hline SIZE & 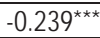 & 1.000 & & & & & & & & & & \\
\hline CATA & \begin{tabular}{|c|}
$-0.14^{*}$ \\
\end{tabular} & $0.399 * \star \star$ & 1.000 & & & & & & & & & \\
\hline SKTA & $0.15^{\star \star}$ & $0.273^{\star \star \star}$ & $0.686^{\star \star \star}$ & 1.000 & & & & & & & & \\
\hline TDTA & $-0.28^{\star \star \star}$ & $0.188^{\star \star \star}$ & $0.68^{\star \star}$ & $0.15^{\star \star}$ & 1.000 & & & & & & & \\
\hline CMSTA & 0.04 & $0.226^{\star \star \star}$ & $0.33^{\star \star \star}$ & $0.31^{\star \star \star}$ & $0.14^{*}$ & 1.000 & & & & & & \\
\hline SGR & -0.06 & $0.194^{\star \star \star}$ & $0.20^{\star \star \star \star}$ & $0.13^{\star}$ & $0.15^{\star \star}$ & 0.08 & 1.000 & & & & & \\
\hline OCFTA & 0.04 & $0.407^{\star \star \star}$ & $0.24^{\star \star \star}$ & $0.17^{\star \star}$ & $0.22^{\star \star \star}$ & $0.13^{\star}$ & $0.19^{\star \star \star}$ & 1.000 & & & & \\
\hline \begin{tabular}{|l|} 
STFDTTA \\
\end{tabular} & $-0.61^{\star \star \star}$ & $0.222^{\star \star \star}$ & $0.34^{\star \star \star}$ & 0.06 & $0.48^{\star \star \star}$ & 0.01 & $0.14^{*}$ & 0.01 & 1.000 & & & \\
\hline LTDTA & $-0.33^{\star \star \star}$ & $-0.205^{\star \star \star}$ & -0.07 & -0.07 & 0.02 & -0.02 & -0.05 & $-0.38^{\star \star \star}$ & -0.07 & 1.000 & & \\
\hline FINCOST & 0.02 & -0.008 & 0.01 & 0.01 & 0.02 & -0.03 & -0.03 & $0.13^{\star}$ & 0.01 & 0.03 & 1.000 & \\
\hline RGDP & -0.06 & 0.039 & 0.05 & 0.06 & 0.04 & 0.07 & $0.17^{\star \star}$ & -0.06 & $0.12^{\star}$ & -0.004 & -0.05 & 1.000 \\
\hline
\end{tabular}

Source: Own calculations based on financial reports obtained from company annual reports

There is a strong negative correlation between short-term and long-term debt and accounts payable which suggests that trade credit is a perfect substitute for these two sources of finance. The correlation between current assets and trade credit is positive as expected and significant at $10 \%$. Of the three components that make up current assets; inventory, trade debtors and cash and marketable securities, only inventory has the expected correlation with accounts payable. Inventory is positive and statistically significant (at $5 \%$ ) correlation with accounts payable. Contrary to expectation, trade debtors have a negative correlation with trade credit, suggesting that as these firms access more suppliers financing, they reduce the credit they extend to their own customers. Cash and marketable securities have a statistically insignificant correlation with trade credit. The proxy for size, the natural logarithm of sales is negatively correlated to trade credit meaning bigger firms are depending less on trade credit. The study did not find any evidence of statistically 
significant correlations between trade credit and the following variables, sales growth, operating cash flows, financing costs and the growth of the economy.

\section{Estimation Results}

With the same dependent variable (accounts payable), two regressions were run under the Random-effects and Fixedeffects models. Post-estimation tests to find the most appropriate model were conducted using the Hausman test. Based on the results obtained, we fail to reject the hypothesis that the individual-level effects are adequately modeled by a random-effects model hypothesis. The coefficient estimates are presented in Table 4.

The study finds a statistically significant negative relationship between firm size and accounts payable, meaning that among these sample firms, the size of the firm does influence dependence on trade credit. This findings is similar to García-Teruel and Martínez-Solano (2010) who found a significant negative relationship between dependence on trade credit and firm size meaning that bigger firms depend less on trade credit because they have wider access to financial markets and other alternative sources of finance.

The relationship between trade credit and operating cashflows is negative as hypothesised but it is not statistically proved. This means that the hypothesis that as the firms generate more their own internal resources they use less trade credit is not confirmed. This also suggests the firm might not be following the POT. The liquidity challenges in the country might be leaving managers with very little room to make financing preferences. In cases of liquidity crunch, accessibility supersedes cost. The average operating cashflows to operating assets is $4 \%$, which is very small, (hence probably explains its failure to influence the use of trade credit.

The study finds a statistically significant negative relationship between trade credit and the two external sources of finance short term debt and long term debt consistent with previous studies (Deloof \& Jegers, 1999; Khan et al., 2012; Niskanen \& Niskanen, 2006). These findings, like previous studies corroborate the POT advanced by S. C. Myers (1984) and S. C. Myers and Majluf (1984). Both short term debt and long term debt are statistically significant at $1 \%$. The coefficient of short term debt is far higher that of long term that short term financial debt is more significant than long term debt and a stronger substitute relationship between short term debt and trade credit. This finding probably also confirms the aversion of financial institutions to engage to long term lending because of liquidity challenges and the uncertainty facing the economy. The relationship between external finance costs and trade credit is not statistically significant which means that the cost of these external finance increases, firms do not necessarily switch to trade credit as an alternative.

Table 4: Multiple Regression Analysis

\begin{tabular}{|l|c|c|c|c|}
\hline \multicolumn{5}{|c|}{ Dependent variable : Accounts payable to total debt (ACPTD) } \\
\hline & \multicolumn{2}{|c|}{ Random effects } & \multicolumn{2}{c|}{ Fixed effects } \\
\hline & $(1)$ & $(2)$ & $(3)$ & $(4)$ \\
\hline OCFTA & -0.0654 & -0.0934 & -0.0427 & -0.0749 \\
\hline & $(-0.79)$ & $(-1.14)$ & $(-0.46)$ & $(-0.79)$ \\
\hline SIZE & $-0.0407^{* *}$ & $-0.0400^{* * *}$ & $-0.0445^{*}$ & -0.0348 \\
\hline & $(-3.16)$ & $(-3.32)$ & $(-2.06)$ & $(-1.62)$ \\
\hline FINCOST & 0.0228 & 0.0244 & 0.0183 & 0.0184 \\
\hline & $(0.72)$ & $(0.78)$ & $(0.55)$ & $(0.55)$ \\
\hline SGR & 0.00138 & 0.00399 & -0.00151 & -0.000247 \\
\hline & $(0.15)$ & $(0.43)$ & $(-0.15)$ & $(-0.02)$ \\
\hline LTDTA & $-0.466^{* * *}$ & $-0.470^{* * *}$ & $-0.376^{* *}$ & $-0.374^{* *}$ \\
\hline & $(-6.27)$ & $(-6.50)$ & $(-3.33)$ & $(-3.33)$ \\
\hline STFDTTA & $-1.352^{* * *}$ & $-1.292^{* * *}$ & $-1.282^{* * *}$ & $-1.206^{* * *}$ \\
\hline & $(-11.02)$ & $(-9.96)$ & $(-8.49)$ & $(-7.58)$ \\
\hline RGDP & 0.000688 & -0.000437 & 0.000680 & 0.000103 \\
\hline & $(0.17)$ & $(-0.11)$ & $(0.16)$ & $(0.02)$ \\
\hline CATA & $0.206^{*}$ & - & 0.216 & - \\
\hline & $(2.36)$ & - & $(1.55)$ & - \\
\hline SKTA & - & $0.409^{* * *}$ & - & $0.308^{*}$ \\
\hline & - & $(3.96)$ & - & $(2.13)$ \\
\hline TDTA & - & 0.0708 & - & -0.0381 \\
\hline & - & $(0.48)$ & - & $(-0.17)$ \\
\hline
\end{tabular}




\begin{tabular}{|l|c|c|c|c|}
\hline CMSTA & - & -0.0539 & - & -0.138 \\
\hline & - & $(-0.26)$ & - & $(-0.61)$ \\
\hline CONS & $1.402^{\text {*** }}$ & $1.391^{\text {*** }}$ & $1.453^{\text {*** }}$ & $1.320^{\text {*** }}$ \\
\hline & $(6.71)$ & $(7.00)$ & $(4.24)$ & $(3.84)$ \\
\hline R SQUARED & 0.5733 & 0.6121 & 0.5633 & 0.5949 \\
\hline
\end{tabular}

p-values in parenthesis *, ** and ${ }^{\star \star \star}$ significant at $10 \%, 5 \%$ and $1 \%$ respectively

Source: Own calculations based on financial reports obtained from company annual reports. Statistical analysis was conducted using STATA 11.

The study found a statistically significant positive relationship between investment in current assets and trade credit, consistent with previous studies (García-Teruel \& Martínez-Solano, 2010; Niskanen \& Niskanen, 2006; Petersen \& Rajan, 1997). Therefore the hypothesis that the more a firm invests in current assets the more a firm demands trade credit from suppliers is confirmed. In column 2 of table 4 the relationship between trade credit and current assets was further analysed using the disaggregated components of currents assets. Only inventory has a statistically significant relationship with trade credit (significant at 5\%), confirming the finding positive correlation found in Table 4 . The significance of inventory is not surprising because trade credit is used to finance the acquisition of inventory hence as the firms holds more inventories it demands more trade credit. The study did not find any evidence of any relationship between cash and marketable securities and trade credit, a contradiction to the finding of (Deloof \& Jegers, 1999). The statistically insignificant coefficient of trade receivables means that the hypothesis that as the firm extends more credit to its customers, it will demand more trade credit from its suppliers to finance its receivables is not confirmed.

The hypothesis the need for funding positively influences the use of trade credit is not confirmed in this study. High sales growth and investment opportunities are associated with high demand for financing requirements and firms tend to use supplier finance to complement other sources of finance. The study finds no evidence that the use of trade credit depends on the state of the economy as represented by RGDP growth rate.

\section{Conclusion}

The aim of the study was to find out factors influencing the use of trade credit as a source of financing for Zimbabwe firms as the country recovers from political social and economic crises. The study used a sample of 48 non-financial firms listed ZSE for the period 2009-2012. The study found that trade credit reliance is mainly influenced by the size of the firm and asset maturity. The negative relationship between trade credit and long-term and short-term debt means that trade credit is being used as substitute for unavailability of credit. It is therefore of paramount importance that managers to pay attention to these factors that influence the use of trade credit as a financing instrument. Maintaining healthy relationships with suppliers is important as it ensures access to goods and "cost-free finance".

\section{References}

Bradelly, D. B., \& Rubach, M. J. (2002). Trade credit and small business: A cause of business failures. http://www.sbaer.uca.edu /research/asbe/2002/papers/02asbe055.pdf

Central Statistical Office, C. (2008). Monthly updates. Harare: Central Statistical Office.

Confederation of Zimbabwe Industries , C. (2011). Manufacturing Survey. Harare Confederation of Zimbabwe Industries

Coricelli, F., \& Masten, I. (2004). Growth and volatility in transition countries: The role of credit. Festschrift in Honor of Guillermo A. Calvo. Washington DC: International Monetary Fund. April.

Cull, R., Xu, L. C., \& Zhu, T. (2009). Formal finance and trade credit during China's transition. Journal of Financial Intermediation, 18(2), 173-192.

Cunat, V. (2007). Trade credit: suppliers as debt collectors and insurance providers. Review of Financial Studies, 20(2), $491-527$.

Deloof, M., \& Jegers, M. (1999). Trade credit, corporate groups, and the financing of Belgian firms. Journal of Business Finance \& Accounting, 26(7-8), 945-966.

Emery, G. W. (1984). A pure financial explanation for trade credit. Journal of Financial and Quantitative Analysis, 19(3), $271-285$.

Fafchamps, M. (1997). Trade credit in Zimbabwean manufacturing. World Development, 25(5), 795-815.

Ferris, J. S. (1981). A transactions theory of trade credit use. The Quarterly Journal of Economics, 96(2), 243-270.

Fisman, R. (2001). Trade credit and productive efficiency in developing countries. World Development, 29(2), 311-321.

Fisman, R., \& Love, I. (2003). Trade credit, financial intermediary development, and industry growth. The Journal of finance, 58(1), 353374.

García-Teruel, P. J., \& Martínez-Solano, P. (2010). A dynamic perspective on the determinants of accounts payable. Rev Quant Finan 
Acc, 34, 439-457. doi: 1007/s11156-009-0124-0

Hill, M. D., Kelly, G. W., \& Highfield, M. J. (2010). Net Operating working capital behaviour: A first look Financial Management (Summer), 783-2010.

Huyghebaert, N., Van de Gucht, L., \& Van Hulle, C. (2007). The choice between bank debt and trade credit inbusiness start-ups. Small Business Economics, 29, 435-452.

International Monetary Fund, I. (2008). World Economic Outlook Database, October 2008.

Khan, M. A., Tragar, G. A., \& Bhutto, N. A. (2012). Determinants of accounts receivable and accounts payable: a case of Pakistan textile sector. Interdisciplinary Journal Of Contemporary Research In Business, 3(9), 240-251.

Long, M. S., Malitz, I. B., \& Ravid, S. A. (1993). Trade credit, quality guarantees, and product marketability. Financial management, 117127.

Ministry of Finance, M. (2006). Budget Statement Harare: Government Printers.

Ministry of Finance, M. (2010). Budget Statement. Harare: Government Printers.

Ministry of Finance, M. (2011). Budget Statement. Harare: Government Printers.

Ministry of Finance, M. (2012). Budget Statement. Harare: Government Printers.

Myers, S. C. (1977). Determinants of corporate borrowings. Journal of Financial Economics, 5(147-175).

Myers, S. C. (1984). The capital structure puzzle. The Journal of finance, 39(3), 574-592.

Myers, S. C., \& Majluf, N. (1984). Corporate financing and investment decisions When firms have information investors do not have. Journal of Financial Economics, 13, 187-221.

Niskanen, J., \& Niskanen, M. (2000). Accounts Receivable and Accounts Payable in Large Finnish Firms Balance Sheets: What Determines Their Levels? The Finnish Journal of Business Economics, 4, 489-503.

Niskanen, J., \& Niskanen, M. (2006). The Determinants of Corporate Trade Credit Policies in a Bank-dominated Financial Environment: the Case of Finnish Small Firms. European Financial Management, 12(1), 81-102.

Petersen, M. A., \& Rajan, R. G. (1997). Trade credit: theories and evidence. Review of Financial Studies, 10(3), 661-691.

Reserve Bank of Zimbabwe, R. (2005). Monetary Policy Statement. . Harare: Reserve Bank of Zimbabwe.

Schwartz, R. A. (1974). An economic model of trade credit: Cambridge Univ Press.

Smith, J. K. (1987). Trade credit and informational asymmetry. The Journal of finance, 42(4), 863-872.

Soenen, L. (1993). Cash Conversion Cycle and corporate profitability. . Journal of Cash Management, 13, 53-57.

Van der Wijst, N., \& Hol, S. (2002). Trade credit in Europe. Paper presented at the Paper presented at the 31st Meeting of the EUROPEAN WORKING GROUP ON FINANCIAL MODELING (EWGFM),, Agia Napa, CYPRUS.

Van Horne, J. C. (2002). Financial Management and Policy (12th ed.). New Jersey Prentice Hall.

Weston, J. F., Besley, S., \& Brigham, E. F. (1996). Essential of Managerial Finance (11th ed.). Forth Worth:: The Dryden Press Harcourt Brace College Publishers. 
